\title{
Evaluate the correlation of Inflammatory Cytokines with Chlamydia pneumonia in Coronary Atherosclerotic Patients
}

\author{
Ruqaya M. AL-Barzinji* \\ Lajan Q. Rahman *
}

\author{
BSc, MSc, PhD \\ BSc, MSc
}

Fac Med Baghdad 2017; Vol.59, No.3 Received: Mar. 2017 Accepted: May 2017
Background: Coronary atherosclerosis is an inflammatory disease, caused by high concentrations of plasma cholesterol, in particular those with high concentrations of low-density lipoprotein cholesterol, which considered as one of the principal risk factors for atherosclerosis.

Objective: The study focused on detecting risk factors and biomarkers for coronary atherosclerotic in order to develop interventions preventing their progressions.

Patients and Methods: The present case control study was carried out between December 2012 and May 2013, in Hawler cardiac center, 74 coronary atherosclerotic patients were enrolled in our study (44 males and 30 females), their age ranged between 30 years to 75 years old, 25 (33.8\%) were type 2 diabetes, 51 $(68.9 \%)$ were hypertensive and $29(39.2 \%)$ were obese. Apparently 40 healthy individuals were also joined in this study. The sera were subjected to assessment of some inflammatory biomarkers including high sensitive C- reactive proten (CRP), Interleukin-6(IL-6), Tumor Necrosis Factor-alpha (TNF- $\alpha$ ), IL-10, leptin, leptin receptor and Chlamydia pneumonia (C.pneumonia).

Results: Serum concentrations of high sensitive CRP, TNF- $\alpha$, C.pneumonia and IL-10 in obese coronary atherosclerotic patients (CAPS) were significantly higher than non-obese patients $(\mathrm{P} \leq 0.01)$, indeed IL-6, leptin and leptin receptor also significantly increased in obese patients $(\mathrm{P} \leq 0.05)$. Same results with serum CRP, IL-6 and IL-10 levels in diabetic patients than non-diabetic patients $(\mathrm{P} \leq 0.05)$. However, TNF- $\alpha$ in diabetic patients was significantly higher than non-diabetic patients $(\mathrm{P} \leq 0.01)$. Serum concentration of high sensitivity CRP in hypertensive patients was statistically significant than non-hypertensive patients $(\mathrm{P} \leq 0.05)$.

Conclusions: Our study revealed that various factors have been introduced in the pathophysiology of atherosclerosis such as: age, sex, diabetes, hypertension, obesity, defect in lipid metabolism and change in the concentration of various lipoproteins of cholesterol.

Key word: Coronary atherosclerotic, cytokines, Chlamydia pneumonia
Introduction:

Cardiovascular diseases (CVDs) are now regarded as the number one cause of death globally and are projected to remain so for many years to come [1], currently the leading cause of death and illness in developed countries [1]. It is well established that vascular inflammation is an independent risk factor for the development of atherosclerosis [2]. Atherosclerosis is a disease characterized by inflammation that usually begins at an early age in the absence of lipid accumulation, with fatty streaks composed of lipidladen (foam) cells developing at later stages. Its development and progression appear to be a balance between pro- inflammatory and regulatory immune responses [1][3]. Leptin is an adipokine with both protective and harmful effects on the cardiovascular system. it promotes atherosclerosis via macrophage leptin receptor[4]. It has been suggested that obesity indirectly promotes the progression of atherosclerotic lesions by inducing a multitude of metabolic and

*Dept. of Microbiology, College of Medicine, Hawler Medical University, Erbil, Iraq.

Email: ruqayataher2012@gmail.com. hemodynamic derangements that have a high atherogenic potential, however, adipocytes also synthesize and secrete a number of hormones, growth factors, cytokines, proteases, and protease inhibitors that might directly contribute to the atherosclerotic and atherothrombotic risk associated with obesity[5]. The possible causes of endothelial dysfunction leading to atherosclerosis include, elevated and modified LDL, free radical (oxidative stress) caused by hyperlipidemia, diabetes, insulin resistance, hypertension, obesity with a chronic and systemic proinflammatory stimulus due to the increased production of cytokines by the adipose tissue[6].

Chlamydia pneumonia is Gram-negative obligate intracellular bacterium is a widespread human pathogen causing respiratory tract infections, including pneumonia. Recently, chronic C. pneumoniae infection has been proposed as a trigger and promoter of inflammatory reactions and development of vascular lesions [7]. Chlamydia pneumonia infect vascular cells, including smooth muscle cells, endothelial cells, macrophages and monocytes, stimulate these cells to produce cytokines, chemokines 
and adhesion molecules[8]. Chlamydial and human heat shock protein 60 are activate endothelial cells, smooth muscle cells and macrophages, by inducing expression of adhesion molecules, production of proinflammatory cytokines and activation of nuclear factor- $\kappa$ B. Fibroblasts are prominent cell population in chronic inflammation and persistent infection, contributing to plaque formation and evolution during atherogenesis. They are involved in the synthesis of collagen and cytokines and are engaged in complex interactions during the inflammatory process[9].

\section{Patients and methods:}

The present case control study was carried out between December 2012 and May 2013, in Hawler cardiac center, 74 coronary atherosclerotic patients were enrolled in our study (44 males and 30 females); their age ranged between (30-75) years with an average of 57.77 years. $25(33.8 \%)$ were type 2 diabetes, 51 (68.9\%) were hypertensive and 29(39.2\%) were obese. Apparently 40 healthy individuals who have no history of clinical evidence of any acute or chronic disease were also joined in this study. All patients were subjected to personal interview through especially designed questionnaires format. Coronary angiograms were performed in all patients. Serum from study groups were subjected to in-vitro assessment of some inflammatory biomarkers including high sensitivity CRP by nephlometer, interleukin-6, tumor necrosis factor alpha, interleukin10 , leptin, leptin receptor and infectious marker like $C$. pneumonia by Enzyme linked immuno-sorbent assay(biotek, USA). SPSS version 20 was used for statistical data analysis.

\section{Results:}

Our study was designed to study some immunological biomarkers such as CRP, IL-6, TNF- $\alpha$, IL-10, $C$. pneumonia $\mathrm{IgG}$, leptin and leptin receptor in studied groups. Twenty five $(33.8 \%)$ were presented with type 2DM, 51(68.9\%) with hypertension and 29 (39.2\%) with obesity. Baseline characteristics of patients with coronary atherosclerosis and healthy control were detailed in table (1). There was a significant difference between the two groups in regards to IL-6, TNF- $\alpha$, leptin and leptin receptor $(\mathrm{P} \leq 0.05)$, and $(\mathrm{P} \leq 0.01)$ regarding total cholesterol, HDL, LDL, TG, BMI, hsCRP, IL-10 and C. pneumoniae.
Table 1: Mean serum concentrations of study parameters among CAPs and healthy control.

\begin{tabular}{|c|c|c|c|}
\hline Characters* & $\begin{array}{l}\mathrm{HC} \\
\text { No.40 }\end{array}$ & $\begin{array}{l}\text { CAPs } \\
\text { No.74 }\end{array}$ & $\mathrm{P}$ value \\
\hline $\begin{array}{l}\text { Age(years): Mean } \pm \\
\text { SE }\end{array}$ & $45.2 \pm 2.38$ & $57.7 \pm 1.02$ & $+\mathrm{S}$ \\
\hline $\begin{array}{l}\text { Sex: No (\%) } \\
\text { Male } \\
\text { Female }\end{array}$ & $\begin{array}{l}20(50) \\
20(50)\end{array}$ & $\begin{array}{l}44(59.50 \\
30(40.5)\end{array}$ & $++\mathrm{NS}$ \\
\hline $\begin{array}{l}\text { Measurements: } \\
\text { Mean } \pm \text { SE }\end{array}$ & & & \\
\hline $\begin{array}{l}\text { Total } \\
\text { cholesterol }(\mathrm{mg} / \mathrm{dl}) \\
\text { Triglycerides }(\mathrm{mg} / \mathrm{dl}) \\
\text { HDL-cholesterol } \\
(\mathrm{mg} / \mathrm{dl}) \\
\text { LDL-cholesterol } \\
(\mathrm{mg} / \mathrm{dl}) \\
\text { Body mass index } \\
\left(\mathrm{kg} / \mathrm{m}^{2}\right)\end{array}$ & $\begin{array}{l}156.5 \pm 5.32 \\
92.78 \pm 5.95 \\
43.0 \pm 1.57 \\
85.64 \pm 6.24 \\
21.97 \pm 1.13\end{array}$ & $\begin{array}{l}\quad 179.06 \\
\pm 5.86 \\
182.21 \\
\pm 11.15 \\
33.04 \pm 0.90 \\
107.89 \pm \\
3.64 \\
24.89 \pm 3.64\end{array}$ & $\begin{array}{l}+\mathrm{HS} \\
+\mathrm{HS} \\
+\mathrm{HS} \\
+\mathrm{HS} \\
+\mathrm{HS}\end{array}$ \\
\hline $\begin{array}{l}\text { Inflammatory } \\
\text { biomarkers: Mean } \\
\pm \text { SE }\end{array}$ & $0.83^{3.92 \pm}$ & 7.414 & \\
\hline $\begin{array}{l}\text { hsCRP }(\mathrm{mg} / \mathrm{l}) \\
\text { IL-6 }(\mathrm{pg} / \mathrm{ml}) \\
\text { TNF- } \alpha(\mathrm{pg} / \mathrm{ml}) \\
\text { IL-10 }(\mathrm{pg} / \mathrm{ml}) \\
\text { Leptin }(\mathrm{ng} / \mathrm{ml}) \\
\text { Leptin } \\
\text { receptor(pg/ml) }\end{array}$ & $\begin{array}{l}10.045 \pm \\
0.58 \\
4.192 \\
\pm 0.163 \\
7.57 \pm 0.524 \\
1.80 \pm 0.340 \\
65.13 \\
\pm 16.05\end{array}$ & $\begin{array}{l} \pm 0.731 \\
13.64 \pm 1.56 \\
4.513 \pm 0.09 \\
6.20 \pm 0.176 \\
3.142 \pm \\
0.417 \\
131.9 \pm \\
25.32\end{array}$ & $\begin{array}{l}+\mathrm{HS} \\
+\mathrm{S} \\
+\mathrm{S} \\
+\mathrm{HS} \\
+\mathrm{S} \\
+\mathrm{S}\end{array}$ \\
\hline $\begin{array}{l}\text { Infectious } \\
\text { biomarker: Mean } \pm \\
\text { SE }\end{array}$ & & & \\
\hline $\begin{array}{l}\text { Chlamydia } \\
\text { pneumonia } \\
\operatorname{Ig} G(\mathrm{IU} / \mathrm{ml})\end{array}$ & $\begin{aligned} & 63.57 \\
\pm & 10.18\end{aligned}$ & $\begin{array}{l}105 \pm \\
5.77\end{array}$ & $+\mathrm{HS}$ \\
\hline \multicolumn{4}{|c|}{$\begin{array}{l}\text { *HsCRP: High sensitivity C- reactive protein; IL-6: Interleukin-6; } \\
\text { TNF- } \alpha \text { : Tumor necrosis factor- } \alpha \text {; IL-10: Interleukin- } 10 \text {; P value } \\
\geq 0.05 \text { : Non Significant; P value } \leq 0.05 \text { : Significant; P } \leq 0.01 \text { : Highly } \\
\text { significant; }+\mathrm{t} \text { test; } \quad++\chi^{2} \text { (chi square) test; CAPs: Coronary } \\
\text { atherosclerotic patients. }\end{array}$} \\
\hline
\end{tabular}

Serum concentrations of hsCRP, TNF- $\alpha, C$. pneumoniaand and IL-10 in obese patients were $9.07 \pm 0.823,4.748 \pm 0.94,6.62 \pm 0.280$ and $120.36 \pm 8.25$, respectively were significantly higher than non-obese patients $(\mathrm{P} \leq 0.01)$. The serum concentrations of IL-6, leptin and leptin receptor were $(12.89 \pm 1.308$, $3.813 \pm 0.65$

and $133.43 \pm 35.45$ ) in obese patients, respectively, which had a statistically significant difference as to non-obese patients $(\mathrm{P} \leq 0.05)$, table $(2)$. 
Table 2: Mean serum concentrations of study parameters among obese and non-obese CAPs.

\begin{tabular}{|c|c|c|c|c|}
\hline \multirow{3}{*}{ Parameters } & \multicolumn{2}{|l|}{ CAPs Patients } & \multirow{3}{*}{$\begin{array}{l}\mathrm{P} \text { value } \\
\text { T-test }\end{array}$} & \multirow{3}{*}{ Probability } \\
\hline & Obese $\quad$ No. 29 & Non obese & & \\
\hline & Mean \pm SE & Mean \pm SE & & \\
\hline HsCRP(mg/L) & $9.07 \pm 0.823$ & $5.12 \pm 0.818$ & 0.0012 & $\mathrm{HS}^{* *}$ \\
\hline IL-6(pg/ml) & $12.89 \pm 1.308$ & $10.085 \pm 0.392$ & 0.058 & $\mathrm{~S}^{*}$ \\
\hline TNF- $\alpha(\mathrm{pg} / \mathrm{ml})$ & $4.748 \pm 0.94$ & $4.2 \pm 0.135$ & 0.002 & $\mathrm{HS}^{* *}$ \\
\hline IL-10(pg/ml) & $6.62 \pm 0.280$ & $5.69 \pm 0.134$ & 0.005 & $\mathrm{HS}^{* *}$ \\
\hline Leptin(ng/ml) & $3.813 \pm 0.65$ & $2.0 \pm 0.359$ & 0.019 & $\mathrm{~S}^{*}$ \\
\hline Leptin receptor $(\mathrm{pg} / \mathrm{ml})$ & $133.43 \pm 35.45$ & $52.28 \pm 6.4$ & 0.03 & $\mathrm{~S}^{*}$ \\
\hline С.pneuтопiae(IU/ml) & $120.36 \pm 8.25$ & $87.615 \pm 6.78$ & 0.003 & $\mathrm{HS}^{* *}$ \\
\hline
\end{tabular}

Serum concentrations of hsCRP, IL- 6 and IL-10 in diabetic patients were $7.24 \pm 0.96,16.55 \pm 3.91$ and $5.92 \pm 0.269$, respectively, with statistically significant difference than non-diabetic patients $(\mathrm{P} \leq 0.05)$. Regarding TNF- $\alpha$ the serum concentration was $4.97 \pm 0.144$ in diabetic patients which was significantly higher than non-diabetic patients $(\mathrm{P} \leq 0.01)$. However, serum concentrations of leptin, leptin receptor and C. pneumoniae were $3.66 \pm 0.83$, $175.0164 \pm 19.27$ and $112 \pm 8.6$ respectively with no statistically significant difference than non-diabetic patients $(\mathrm{P} \geq 0.05)$, table (3). Serum concentration of hsCRP in hypertensive patients was $6.67 \pm 0.609$ that was statistically significant different than nonhypertensive patients $(\mathrm{P} \leq 0.05)$.However, serum concentrations of IL-6, TNF- $\alpha$, IL-10, leptin, leptin receptor and $C$. pneumonaie in hypertensive patients were $\quad 15.299 \pm 2.567, \quad 4.611 \pm 0.10, \quad 6.360 \pm 0.26$, $3.64 \pm 0.779, \quad 159.65 \pm 39.2$ and $97.154 \pm 6.48$, respectively, with no statistically significant difference than non-hypertensive patients ( $\mathrm{P} \geq 0.05)$, table (4).

Table 3: Mean serum concentrations of study parameters among D.M and Non D.M CAPs.

\begin{tabular}{|c|c|c|c|c|}
\hline \multirow{3}{*}{ Parameters } & \multicolumn{2}{|r|}{ CAPs Patients } & \multirow{3}{*}{$\begin{array}{l}P \text { value } \\
\text { t-test }\end{array}$} & \multirow{3}{*}{ Probability } \\
\hline & $\begin{array}{l}\text { D.M } \\
\text { No. } 25\end{array}$ & $\begin{array}{l}\text { Non D.M } \\
\text { No. } 49\end{array}$ & & \\
\hline & Mean $\pm \mathrm{SE}$ & Mean $\pm \mathrm{SE}$ & & \\
\hline HsCRP(mg/L) & $7.24 \pm 0.96$ & $4.832 \pm 0.26$ & 0.023 & $\mathrm{~S}^{*}$ \\
\hline IL-6(pg/ml) & $16.55 \pm 3.91$ & $11.19 \pm 0.768$ & 0.048 & $\mathrm{~S}^{*}$ \\
\hline TNF- $\alpha(\mathrm{pg} / \mathrm{ml})$ & $4.97 \pm 0.144$ & $4.34 \pm 0.098$ & 0.001 & $\mathrm{HS}^{*}$ \\
\hline IL-10(pg/ml) & $5.92 \pm 0.269$ & $6.34 \pm 0.22$ & 0.02 & $\mathrm{~S}^{*}$ \\
\hline Leptin(ng/ml) & $3.66 \pm 0.83$ & $3.16 \pm 0.49$ & 0.612 & NS \\
\hline $\begin{array}{l}\text { Leptinreceptor } \\
\text { (pg/ml) }\end{array}$ & $\begin{array}{l}175.01 \\
\pm 19.27 \\
\end{array}$ & $84 \pm 16.850$ & 0.06 & NS \\
\hline $\begin{array}{l}\text { C.pneumoniae } \mathrm{IgG} \\
\text { (IU/ml) }\end{array}$ & $112 \pm 8.68$ & $102.22 \pm 7.5$ & 0.336 & NS \\
\hline
\end{tabular}


Table 4: Mean concentrations of study parameters among HTN and Non HTN

\begin{tabular}{|c|c|c|c|c|}
\hline \multirow{3}{*}{ Parameters } & \multicolumn{2}{|l|}{ CAPs Patients } & \multirow{3}{*}{$\begin{array}{l}\mathrm{P} \text { value } \\
\text { T-test }\end{array}$} & \multirow{3}{*}{ Probability } \\
\hline & No. 51 & Non HTN & & \\
\hline & Mean \pm SE & Mean \pm SE & & \\
\hline $\operatorname{HsCRP}(\mathrm{mg} / \mathrm{L})$ & $6.67 \pm 0.609$ & $5.175 \pm 0.4702$ & 0.04 & $\mathrm{~S}^{*}$ \\
\hline IL-6(pg/ml) & $15.299 \pm 2.567$ & $11.36 \pm 1.088$ & 0.280 & NS \\
\hline $\mathrm{TNF}-\alpha(\mathrm{pg} / \mathrm{ml})$ & $4.611 \pm 0.10$ & $4.47 \pm 0.157$ & 0.455 & NS \\
\hline IL-10(pg/ml) & $6.360 \pm 0.26$ & $5.99 \pm 0.212$ & 0.280 & NS \\
\hline Leptin(ng/ml) & $3.64 \pm 0.779$ & $3.11 \pm 0.485$ & 0.569 & NS \\
\hline Leptin receptor(pg/ml) & $159.65 \pm 39.2$ & $93.59 \pm 25.579$ & 0.163 & NS \\
\hline C.pneumoniaeIgG(IU/ml) & $97.15 \pm 6.48$ & $86.96 \pm 6.63$ & 0.276 & NS \\
\hline
\end{tabular}

\section{Discussion:}

Several epidemiological studies have provided evidence that serum markers of inflammation are associated with conventional risk factors during atherosclerotic diseases [10]. The average age of patients in current study seems to be similar with those participated in other studies such as Babu et al.,[11]due to most frequently complications located at this age group. Concerning the gender, number of male patients was higher than female. Hormonal and physiological differences between female and male play an important role in increasing the risk of disease. Estrogen hormone is cardio protective agent that maintains NO in the endothelium of blood vessels, its high level in women protects them from risk of coronary atherosclerosis before menopause [12]. Our result is inconsistent with previous study done by Towfighi et al. [13], who stated that coronary atherosclerosis were more severe and extensive in women than men and this could be explained from the age of the majority women that enrolled in their study were above 60 years, postmenopausal women in that study had low HDL as anti- risk factor. Concordant with previous study [14] our study has shown that circulating levels of inflammatory biomarkers (hs CRP, IL-6, TNF- $\alpha$, leptin and leptin receptor) were significantly higher in obese CAPs than non- obese CAPs. IL-10 as an anti-inflammatory cytokine was lower in obese CAPs than non- obese CAPs. Plasma CRP level is sensitive marker of systemic inflammation and may reflect the amount and activity of pro-inflammatory cytokines, obesity is directly associated with increased plasma level of hsCRP. CRP synthesis in the liver is under the control of IL-6, TNF$\alpha$ and leptin, thus adipocytes not only secretes leptin but also contributes to the CRP synthesis. The only source of leptin is adipocytes, which are also an important source of circulating IL-6 and TNF- $\alpha$ [15]. Leptin up regulates the pro-inflammatory cytokines like IL-6 and TNF- $\alpha$ which down regulates the antiinflammatory cytokines like IL-10. LepR has been shown to have signaling capabilities similar to IL-6 type cytokine receptors. Therefore, it is likely that leptin may act $\mathrm{f}$ via IL-6, or perhaps via lepR to up regulate CRP production [16]. The findings of this study support the hypothesis that $C$. pneumoniae is associated with atherosclerosis [17]. Indeed, our result showed a significant relationship between obesity and C. pneumoniae which was consistent with some studies in this field [18, 19]. Presence of atherosclerosis in patients with high circulating level of $C$. pneumoniae can be related to these effects, direct effect of $C$. pneumoniae on endothelium and their growth in endothelial cells and direct effect of microorganism in preparing macrophages for absorption of oxLDL which is the first step in atherogenesis initiation, therefore the presence of $C$. pneumonia along with oxidative factors and oxidation can be possibly more important than hypercholesterolemia in the pathogenesis of atherosclerosis[20]. In the present study there were elevated circulating level of hsCRP, IL- 6 and TNF- $\alpha$ and decreased circulating level of IL-10 in diabetic CAPs than non- diabetic CAPs. Similar results was obtained by Smith et al., (1999)[21]who stated that diabetic patients have increased level of hsCRP, IL-6 and TNF- $\alpha$ which suggests a role for systemic inflammation in diabetogenesis and insulin resistance syndrom[22]. Similar results were also obtained from many other studies; one of which showed that the mean concentration of CRP and IL-6 in CAPs having DM were significantly higher when compared to nondiabetic patients [23]. Another group of workers mentioned that a cross sectional study in established diabetic patients confirmed that the level of CRP, IL-6 and TNF- $\alpha$ were elevated when comparison to nondiabetic patients [24]. Diabetes is significant risk factor for atherosclerosis; the diabetic state promotes oxidative stress mediated by ROS, these consume NO and lead to endothelial dysfunction [25]. In the present study the circulating level of IL-10 was found to be decreased in diabetic CAPs when compared to nondiabetic CAPs. A similar finding was obtained from 
previously published report by Landmesser et al., (2003)[26]. IL-10 was experimentally shown to impede endothelial dysfunction during development of diabetes via reducing the production of superoxide anions [27]. Among patients with hypertension, several clinical studies have demonstrated increased numbers of well recognized pro-inflammatory markers such as hsCRP in patients with hypertension [28]. Furthermore elevated hsCRP levels have also been shown to be predictive for the development of hypertension in prehypertensive and normotensive patients [29]. Similar result was obtained from our study; circulating level of hsCRP was higher in hypertensive than non-hypertensive patients. Hypertension reduces NO synthesis or release which leads to endothelial dysfunction then this finally lead to thickness of conduit vessels such as common carotid artery and so contribute in pathophysiology of coronary atherosclerosis [30].

\section{Conclusion:}

Progression of atherosclerosis related to the presence of C. pneumoniae antibodies. Indeed, leptin, leptin receptor, hsCRP, TNF- $\alpha$, IL-10 and IL-6 measurements can be a good prognostic value in coronary atherosclerosis patients.

\section{Authors' contribution:}

Ruqaya Muhammed Ghareeb Taher AL-Barzinji: Supervisor

Lajan Qasim Rahman: MSc Students

\section{References:}

1- WHO. Cardiovascular Diseases, Factsheet: (Accessed on 2015 May 02).

2-Brasier A, Recinos A, Eledrisi M. (2002). Vascular inflammation and the renin-angiotensin system. ArteriosclerThrombVascBiol; 22(8):1257-66.

3-Farmer J. A. and G. Torre-Amione. (2002). Atherosclerosis and inflammation. CurrAtheroscler Rep;4(2):92-8.

4-Kang S, Kwon H, Hong B, Kim D, Kim I, Choi E et al., (2000). Expression of leptin receptor $(\mathrm{Ob}-\mathrm{R})$ in human atherosclerotic lesions: potential role in intimal neovascularization. Yonsei Med J; 41:68-75. 5-Ginsberg. (2000). HN. Insulin resistance and cardiovascular disease. J Clin Invest;106:453-458.

6-Montani J, Antivc V, Yang Z, and Dulloo A. (2002). Pathways from obesity to hypertension: from the perspective of a vicious triangle. Int $J$ ObesRelatMetabDisord; 26:S28-S38.

7-Krüll, M, Klucken, A, Wuppermann, F. (1999). Signal transduction pathways activated in endothelial cells following infection with Chlamydia pneumoniae. J Immunol; 162, 4834-4841.

8- Molestina RE, Miller RD, Lentsch AB, Ramirez JA and Summersgill J T (2000) Requirement for $N F-\kappa B$ in transcriptional activation of monocyte chemotactic protein 1 by Chlamydia pneumoniae in human endothelial cells. Infect. Immun. 68:4282-4288.

9-Bulut $Y$, Faure E, Thomas L, Karahashi H, Michelsen K, Equils O, et al., (2002). Chlamydial heat shock protein 60 activates macrophages and endothelial cells through Toll-like receptor 4 and MD2 in a MyD88-dependent pathway. J Immunol; 168, 1435-1440.

10-Elkind M, Cheng B, Boden-Albala T, Runde, J, Thomas H, Chen L, Rabbani et al., (2002). Tumor necrosis factor receptor levels are associated with carotid atherosclerosis. Stroke; 33(1):31-7.

11- Babu $M$, Nagaraja B, Reddy $K$ B(2015).Prevalence and distribution of atherosclerosis in different age groups in Tirupati area AP-Autopsy based study. The Pharma Innovation Journal; 5(1): 87-91.

12-Ha Park K and Park WJ(2015). Endothelial Dysfunction: Clinical Implications in Cardiovascular Disease and Therapeutic Approaches. J Korean Med Sci; 30(9): 1213-1225.

13- Towfighi A, Zheng L, Ovbiagele B. Sex-specific trends in midlife coronary heart disease risk and prevalence. Arch Intern Med.2009;169:1762-6.

14-Ziccardi P, Nappo $F$, Giugliano $G$, Esposito $K$, Marfella R, Cioffi M, et al., (2002). Reduction of inflammatory cytokine concentrations and improvement of endothelial functions in obese women after weight loss over one year. Circulation; 105 (3):804-809.

15-Mohamed-Ali V, Goodrick S, Rawesh A. (1997). Subcutaneous adipose tissue releases interleukin-6, but not tumor necrosis factor-alpha, in vivo. $J$ ClinEndocrinolMetab; 82 (4):4196-200.

16-Mattioli B, Straface E, Quaranta MG, Giordani L, Viora M. (2005). Leptin promotes differentiation and survival of human dendritic cells and licenses them for Th1 priming. J Immunol; 174 (4):6820-8.

17-Assar O, Nejatizadeh A, Dehghan F, Kargar M, Zolghadri N.( 2016). Association of Chlamydia Pneumoniae Infection With Atherosclerotic Plaque Formation; Global Journal of Health Science; 8(4): 1916-9744.

18-Thjodleifsson B, Olafsson I, GislasonD, Gislason T, Jogi R, Janson C, et al., (2008). Infections and obesity: A multinational epidemiological study. Scand J Infect Dis; 40(5):381-6.

19-Rantala A, Lajunen $T$, Juvonen $R$, Bloigu A, Paldanius $M$, Silvennoinen-Kassinen $S$, et al., (2010).Chlamydia pneumoniae infection is associated with elevated body mass index in young men. Epidemiol Infect;138(9):1267-73

20-Pesonen E, Tiirola T, Andsberg E, Jauhiainen M, Paldanius M, Persson K, et al.,(2009). Serum chlamydial lipopolysaccharide as a prognostic factor for a new cardiovascular event. Heart Lung;38(3):176-81. 
21-Smith J, Dykes R, Douglas J. (1999). Long-term exercise and atherogenic activity of blood mononuclear cells in persons at risk of developing ischemic heart disease. JAMA; 281:1722-1727.

22-Festa A, D'Agostino R, Howard G. (2000). Chronic subclinical inflammation as part of the insulin resistance syndrome: the Insulin Resistance Atherosclerosis Study (IRAS). Circulation; 102:42-47. 23-Thorand B, Lowel $H$, Schneider A, Kolb $H$, Meisinger C. (2000). CRP as predicts for incident DM among middle aged man. Arch. Intern. Med; 163: 9399.

24-Pickup J. (2004). Inflammation and activated innate immunity in the pathogenesis of type 2 diabetes. Diabetes care; 27(3): 813-823.

25-Shishehbor M. and Bhatt D. (2004). Inflammation and atherosclerosis current atherosclerosis.Reports; 6: 131- 139.

26-Landmesser Â,Dikalov $\hat{A}$, Price ÂS. (2003).

$\hat{A}$ Oxidation of tetrahydrobiopterin leads to uncoupling of endothelial cell nitric oxide synthase in hypertension, $\hat{A}$ J Clin Invest; 111: 1201-1209.

27-Gunnett $\hat{A}$, Heistad $\hat{A}, \quad$ Faraci $\hat{A}$. (2002).Â Interleukin-10 protects nitric oxidedependent relaxation during diabetes. Role of superoxide, Â Diabetes; 51: 1931-1937.

28-Bautista LE. (2003). Inflammation, endothelial dysfunction, and the risk of high blood pressure: epidemiologic and biological evidence. J Hum Hypertens; 17: 223-30.

29-King D, Egan B, Mainous A,Geesey M. (2004). Elevation of Creactive protein in people with prehypertension. J Clin Hypertens (Greenwich); 6: 562-8.

30- Oparil S, Zaman M. and Calhoun D. (2003). Pathogenesis of hypertension. Ann. Mad; 139(9):761776. 